\title{
Wavelength-dependent absorption and scattering effects on laser cleaning of a corroded iron alloy European scale armor
}

\author{
Marlene April Yandrisevits ${ }^{1,2 \star}$, Pablo Londero ${ }^{3}$, Federico Carò ${ }^{1}$, \\ Adriana Rizzo ${ }^{1}$, Caterina Cappuccini ${ }^{1}$ \\ 1 The Metropolitan Museum of Art, 1000 Fifth Avenue, New York, NY 10028, USA \\ 2 Smithsonian National Air and Space Museum, Steven F. Udvar-Hazy Center, 14390 Air and Space \\ Museum Parkway, MRC 326, Chantilly, VA 20151, USA \\ 3 Institute for the Preservation of Cultural Heritage, Yale University, 300 Heffernan Road, Bldg. 800, \\ West Haven, CT 06516, USA \\ * Corresponding author: marlene.yandrisevits@metmuseum.org
}

\begin{abstract}
This research seeks to optimize Nd:YAG laser cleaning parameters for the removal of corrosion products on historic iron alloy surfaces. This article presents the treatment of a $19^{\text {th }}$-century, European scale armor jazeran in the collection of the Arms and Armor Department at The Metropolitan Museum of Art. Laser cleaning was coupled with traditional mechanical cleaning techniques to increase the time efficiency of treatment while best preserving the composite material construction of the artifact and the aesthetic expectations of treatment. Laser cleaning using an $8 \mathrm{~ns}$, Q-switched, Nd:YAG laser at $532 \mathrm{~nm}$ was found more effective at corrosion removal and less damaging to the underlying metal surface than laser cleaning at $1064 \mathrm{~nm}$. Wavelength-dependent absorption and scattering effects on the laser cleaning of the corroded iron alloy surfaces were investigated. The composition, morphology, and stratigraphy of the corrosion layers were characterized and the effects of laser cleaning of these corrosion layers at $1064 \mathrm{~nm}$ and $532 \mathrm{~nm}$ were examined using stereomicroscopy, scanning electron microscopy - energy dispersive spectroscopy and back-scattered and secondary electron imaging, Raman spectroscopy, Fourier transform - infrared spectroscopy, and thermally assisted hydrolysis and methylation - gas chromatography - mass spectrometry. It was found that the success of the $532 \mathrm{~nm}$ laser cleaning is consistent with the green laser's more resonant energy absorption and decreased scattering length as compared to $1064 \mathrm{~nm}$. These data were used to optimize the optical parameters of the laser energy interaction with the corrosion products to develop more effective and safer laser cleaning profiles for the removal of ferrous corrosion layers on the historic iron alloy surface.
\end{abstract}

Keywords: laser cleaning, iron, wavelength, absorption, scattering, armor

\section{Introduction}

The reduction of thick corrosion layers from historic iron artifacts has traditionally been accomplished through mechanical or chemical techniques. Mechanical methods typically employ an abrasive compound or sharp tool to separate corrosion layers from the underlying metal through physical forces. Chemical means often utilize $\mathrm{pH}$, reducing/ 
oxidizing agents, chelators, or electrical charge to solubilize or convert corrosion products on the metal surface. For some iron surfaces, however, traditional corrosion removal approaches may prove non-ideal. Mechanical and/or chemical techniques may lack adequate precision or control, may jeopardize adjacent alloys and/or associated non-metallic materials, might create an undesired surface appearance, or may be prohibitively time-consuming for effective treatment. As alternative treatment methods are explored, laser cleaning has become increasingly popular as a conservation tool for reducing corrosion layers from historic metals. In laser cleaning, the laser energy parameters can be tailored to remove metal oxides and other undesired surface material without damaging the underlying metal alloy.

For some metal surfaces, laser cleaning can prove more time efficient in reducing corrosion layers and more precise and controllable in protecting underlying and adjacent historic materials than traditional treatment methods, thereby increasing the efficacy of treatment and promoting the overall preservation of the artifact. After laser cleaning, the metal surface might still be treated using traditional finishing methods to achieve the desired surface aesthetic and to promote corrosion resistance.

\subsection{Background}

Laser cleaning as a tool for the removal of corrosion layers from metal surfaces has been investigated widely [1-4]. While much research has focused on copper alloys [5-13] and gilt surfaces [6,14-17], equally significant work has sought to characterize the cleaning of iron alloys by lasers [18-32].

Studies on the laser cleaning of corroded metal alloys often characterize the effects of variances in laser wavelength and/or pulse duration on corrosion removal and metal substrate preservation $[1,3,21,24,25,27$, 28]. Considering the diversity of corrosion compositions and laser parameters, it is unsurprising that these studies do not present complete agreement on optimized factors in the laser cleaning of iron. Some studies cite improved iron corrosion removal utilizing a $532 \mathrm{~nm}$ wavelength [25], while others promote $1064 \mathrm{~nm}[21,24]$, and still others find no distinguishing results [28]. It is generally agreed that a shorter pulse duration reduces thermal effects and lessens the risk of micromelting [1, 24, 33]. Hypotheses toward laser parameter optimization posit the critical roles of laser fluence $[3,21,27$, 28], materials absorptivity [1, 3, 23, 24, 27], and thermal conductivity $[1,34]$ in the safe and effective removal of corrosion layers.

Other typical studies compare the efficacy of laser cleaning against conventional abrasive methods for corrosion removal [21, 25, 27-29]. General conclusions suggest that laser cleaning better preserves surface topography [27, 29]; however, laser cleaning introduces the risks of micromelting and/ or redeposition of ablated material [10, $20,24,26,27]$. Many studies conclude that optimized iron corrosion removal combines laser cleaning and traditional mechanical techniques, citing a limit to the effectiveness of lasers in removing very thick corrosion layers or particular corrosion species $[18,21$, $23,26,28]$.

This study investigates the effect of wavelength variance on corrosion removal and underlying metal preservation in the laser cleaning of a historic iron alloy, with particular consideration given to wavelength-dependent absorption and scattering effects. The impact of laser cleaning used in combination with traditional mechanical 
techniques on the time efficiency of treatment is also evaluated.

\subsection{Case Study}

In this study, laser cleaning is coupled with traditional mechanical cleaning techniques to reduce thick corrosion layers on the iron alloy surfaces of a late $19^{\text {th }}$-century, European scale armor jazeran (Gift of Ordinance Dept., U.S. Army, through Chief Engineering Dept., 1919; 19.49.16) in the collection of the Arms and Armor Department at The Metropolitan Museum of Art in New York (Fig. 1).

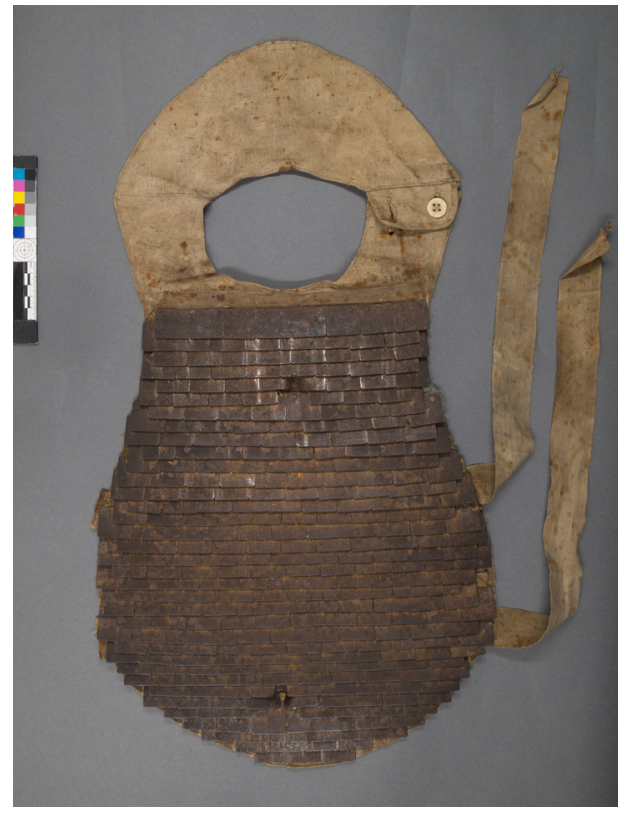

Fig. 1. The $19^{\text {th }}$-century, European scale armor (19.49.16) in the collection of the Arms and Armor Department of The Metropolitan Museum of Art which was the subject of this case study in laser cleaning of a corroded historic iron alloy surface.

The artifact belongs to a class of body defense worn to protect the breast and upper abdomen and is a variant on European scale armor typified by earlier brigandines [35].
The armor was gifted to The Met in 1919 by the Ordinance Department of the United States Army, in which The Met's founding Arms and Armor curator Bashford Dean served during the First World War [36]. Dean received his Army commission to research historic armors to design contemporary helmets and body defense for US armed forces; the jazeran of this case study featured in Dean's military experiments on ballistic resistance [37].

The armor consists of small, flat iron alloy rectangular plates which are riveted to both sides of textile strips subsequently sewn in overlapping horizontal rows across a bib-shaped textile support with textile back straps and bone collar buttons. The alloy composing the metal scales is observationally identified as "low carbon steel" [38]. No metallurgical testing was undertaken to characterize the composition of the alloy, as destructive testing was deemed too invasive; however, qualitative energy dispersive - $\mathrm{x}$-ray fluorescence spectroscopy confirms the ferrous nature of the metal and the lack of any surface enrichment or plating layers.

The surface of the armor's metal scales displays thick, non-homogenous corrosion layers (Fig. 2). The corrosion cross-section generally consists of localized surface spots

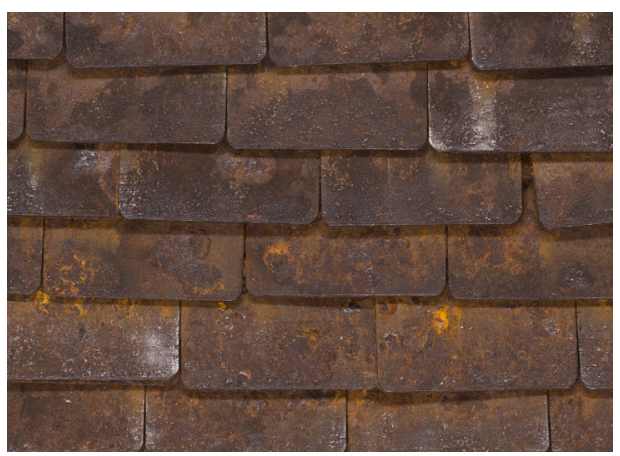

Fig. 2. Thick, non-homogenous corrosion layers on the surface of the armor's metal scales. 
of bright orange, friable corrosion; underlying compact, dark corrosion; and a lowest overall layer of red corrosion. A translucent film overlies the corrosion layers locally. The metal surface underneath the corrosion layers was darkly pitted in some areas, but brightly intact in other areas. It was decided for treatment that all corrosion layers would be reduced to reveal the aged, but clean, dark pitting patina of the underlying metal.

Comingling of the metal and textile elements within the object's construction complicated treatment. Often in the treatment of composite artifacts, components of different material types may be separated or masked to reconcile incompatibilities based on compositional sensitivities. In the case of this armor, with metal scales riveted on both sides of fabric supports, two material types with significantly different treatment vulnerabilities are permanently affixed and in intimate contact (Fig. 3).

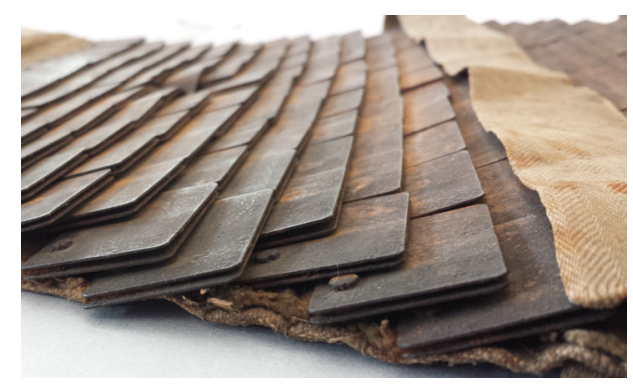

Fig 3. The armor's metal scales as riveted in rows to both sides of textile strips sewn onto a textile support.

With the pale fabric in such close proximity, corrosion reduction on ferrous scales by traditional mechanical techniques proceeded slowly and with limited lubrication to avoid saturation and possible staining of the textile. Mechanically reducing the extensive, thick corrosion layers using this restrained methodology proved time-consuming, and alternate options were pursued. Through analytical investigation and empirical testing, the surface corrosion was characterized and a treatment protocol was optimized combining laser cleaning and mechanical cleaning for the efficient and safe reduction of corrosion from the iron alloy armor scales.

\section{Methods of Analysis and Testing}

The composition, morphology, and stratigraphy of the corrosion layers were characterized and the effects of laser cleaning of these corrosion layers at $1064 \mathrm{~nm}$ and $532 \mathrm{~nm}$ were examined using stereomicroscopy, scanning electron microscopy - energy dispersive spectroscopy (SEM-EDS) and back-scattered and secondary electron (SEM-BSE and SEM-SE) imaging, Raman spectroscopy (Raman), Fourier transform - infrared spectroscopy (FTIR), and thermally assisted hydrolysis and methylation - gas chromatography - mass spectrometry (THM-GC-MS). The metal alloy composition was characterized using energy dispersive $\mathrm{x}$-ray fluorescence spectroscopy (ED-XRF).

\subsection{Stereomicroscopy}

Initial visual assessment of surface corrosion was performed using a Zeiss Discovery V12 stereomicroscope. The surface was illuminated from the side using a Scott white LED source. Low magnification visible images were taken using a Canon EOS-6D attached to the Discovery microscope, highly magnified visible images of the single plate were taken using a Keyence VHX-500 digital microscope, and highly magnified images of scrapings were taken using an Infinity-2 camera attached to a Bruker Senterra Raman microscope. 
2.2. Scanning Electron Microscopy - Energy

Dispersive Spectroscopy/ Backscattered

Electron Imaging/Secondary Electron

Imaging

The scale surface was analyzed by SEM-EDS and imaged with SEM-BSE/SE to investigate the composition and morphology of various corrosion products and surface features. SEM-EDS data was taken using a Zeiss Sigma HD VP electron microscope, equipped with an Oxford Instrument $\mathrm{X}$-MaxN 80 SDD detector. Samples were imaged and analyzed both in low and high vacuum, at a working distance of $8.5 \mathrm{~mm}$ and with a $20 \mathrm{kV}$ source.

\subsection{Raman Spectroscopy}

Scraping samples of each surface layer were analyzed using Raman spectroscopy to characterize corrosion species present. Raman spectroscopy was performed using a Bruker Senterra operating at $10 \mathrm{~mW}$ of power with an excitation wavelength of 785 $\mathrm{nm}$. The spectra were recorded at a resolution of $3-5 \mathrm{~cm}^{-1}$. Integration time and number of acquisitions varied depending on the signal and fluorescence levels of different samples, between 10-60 s and 2-12 acquisitions. The data was compared to an internal Raman reference spectral database which agglomerated data from various sources including RRUFF, the Tate Pigment Library, University College London, and self-made reference libraries.

\subsection{Fourier Transform -}

\section{Infrared micro-Spectroscopy}

Scraping samples of the translucent overlying film were crushed in a diamond compression cell (Spectra Tech) and analyzed by Fourier transform infrared micro-spectroscopy
(micro-FTIR) in transmission mode to characterize the composition. A Hyperion 3000 Microscope interfaced to a Tensor 27 spectrometer (Bruker Optics) equipped with a 15x FTIR objective and a liquid nitrogen-cooled, mercury cadmium telluride (MCT) detector was used. The FTIR spectra were acquired as a sum of 32 scans in the range 4000 to $600 \mathrm{~cm}^{-1}$ and $4 \mathrm{~cm}^{-1}$ resolution. An in-house made reference spectral library was used for data comparison.

\subsection{Thermally-assisted Hydrolysis and Methylation - Gas Chromatography - Mass Spectrometry}

A scraping sample of the translucent overlying film was analyzed by thermally assisted hydrolysis and methylation-gas chromatography/mass spectrometry (THM-GC/ MS) to clarify its organic composition. The sample for analysis measured $64 \mu \mathrm{g}$. The sample was accurately weighed on an Ultramicrobalance UMX2 (Mettler Toledo) in the pyrolysis cup (Eco-cup, Frontier lab) and treated with $3 \mu \mathrm{L}$ of (tetramethyl) ammonium hydroxide (TMAH) $25 \%$ in methanol. THM was performed at $550^{\circ} \mathrm{C}$ in the vertical micro-furnace of the double-shot 2020iD pyrolyzer (Frontier lab), equipped with the Auto-Shot sampler AS-1020E (Frontier lab). The micro-furnace is interfaced to the gas chromatograph Agilent 6890 coupled with the Agilent 5973 Network Mass Selective Detector. The analysis was carried out in split mode 20/1. A J\&W DB-5MS capillary column $(30 \mathrm{~m} \times 0.25 \mathrm{~mm} \times 0.25 \mu \mathrm{m})$ was used for the chromatographic separation. The inlet was kept at $320^{\circ} \mathrm{C}$ and the MS transfer line at $320^{\circ} \mathrm{C}$. Helium was used as the carrier gas, constant flow $1.5 \mathrm{~mL} / \mathrm{min}$. The GC oven temperature program was: $40^{\circ} \mathrm{C}$ for $1 \mathrm{~min}$ ramped to $320^{\circ} \mathrm{C}$ at $10^{\circ} \mathrm{C} / \mathrm{min}$, followed by 
$15 \mathrm{~min}$ isothermal period. Acquisition was performed in SCAN mode (m/z 35-600) with temperatures at MS Source $230^{\circ} \mathrm{C}$ and at Quadrupole $150^{\circ} \mathrm{C}$.

\subsection{Energy Dispersive X-Ray Fluorescence Spectroscopy}

Qualitative ED-XRF analysis was performed to characterize the metal alloy composition and to detect any surface enrichment or plating layers. No samples were taken; the analysis was performed with the instrument in contact with areas of uncorroded metal surface on scale undersides. A Bruker Tracer III-SD portable spectrometer with a rhodium anode tube and no filter run in air at $40 \mathrm{kV}$ and $9.60 \mathrm{~mA}$ for $60 \mathrm{~s}$ live time irradiation was used. Spectral data was collected and analyzed using S1 PXRF software.

\subsection{Laser Cleaning}

Laser cleaning tests were performed using a Quanta Systems Thunderart Nd:YAG Q-switched laser at $1064 \mathrm{~nm}$ and $532 \mathrm{~nm}$ outputs with a pulse duration of $8 \mathrm{~ns}$, a Gaussian beam spot of $10 \mathrm{~mm}$ at its fixed focus, and a repetition rate of $2 \mathrm{~Hz}$.

\section{Characterization of Surface Layers}

To optimize the laser cleaning protocol, it was important to understand the species and stratigraphy of corrosion present.

A discrete scale (measuring $30 \times 26 \times$ $2 \mathrm{~mm}$ ) which had previously detached from the armor was used for surface characterization and cleaning tests. Corrosion layers on the scale's surface were observed under stereomicroscopy. The scale was then placed inside the SEM chamber and its surface imaged through BSE and SE, as well as analyzed by EDS. Next, scrapings of corrosion layers were taken for analysis by Raman spectroscopy and SEM-EDS. Finally, the translucent film was sampled for investigation by FTIR and THM-GC-MS.

In order to determine the basic corrosion stratigraphy, observations under stereomicroscopy were combined with SEM imaging and point-based EDS analysis. It was deemed too destructive to take cross-sectional samples; however the gaps and local variations in the surface composition proved sufficient to establish the layered structure. The proposed multi-layered surface corrosion stratigraphy is shown in (Fig. 4).

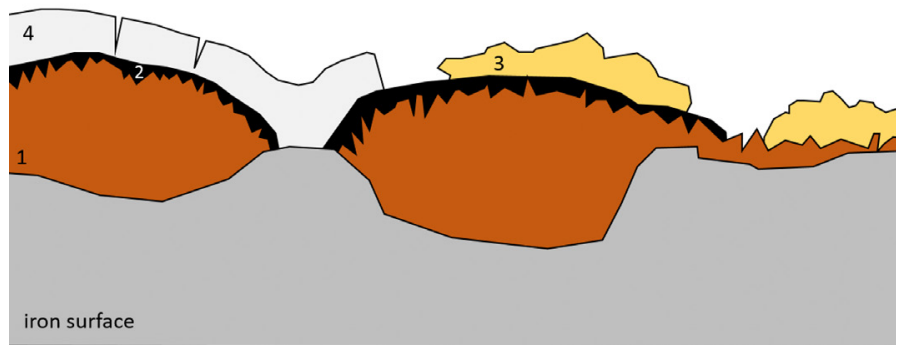

Fig. 4. Diagram showing the proposed multilayered surface corrosion stratigraphy: 1) matte, red layer consisting primarily of lepidocrocite; 2) compact, dark layer of magnetite; 3) fluffy, bright orange layer consisting predominantly of goethite; and 4) translucent film composed of waxes/oils and iron oxalates. Scale is arbitrary. 
Stereomicroscopy revealed the scale's iron alloy surface to be covered by layers of non-uniform, irregular corrosion products of varying color and texture (Fig. 5). Four visually distinct layers were observed in basic stratigraphy, from the metal scale upward: (1) a matte, red layer covering most of the iron alloy surface, over which (2) a compact, dark layer was often present, further topped locally by (3) a fluffy, bright orange layer; in some areas, (4) a brittle, translucent film of variable color was present on top. The layered structure varied locally, with surface corrosion measuring 500 microns at its thickest. Layers (1) and (2) are the most widely distributed across the armor's surface area, while layers (3) and (4) are more localized to areas of overlapping contact between scale layers.

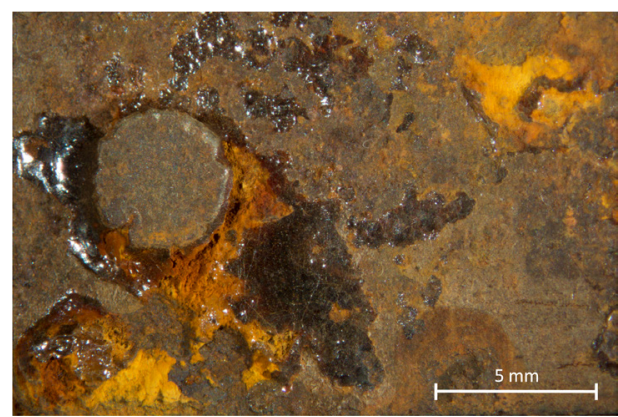

Fig. 5. Stereomicrograph showing the varying color and texture of corrosion products on the metal surface.

To clarify the stratigraphy and composition of the corrosion layers, $\sim 400 \times 500 \mathrm{~mm}$ areas representative of each of the distinct surface layers of the scale were imaged by SEM-BSE-SE. Point-based SEM-EDS analysis was then applied to the typical morphological structure of the different iron oxides and oxyhydroxides observed in each layer to inform characterization of the corrosion species. The matte, red layer (1) exhibits predominantly platy crystals of lepidocrocite ranging in size from $1-5 \mu \mathrm{m}$, stacked and/or interlocked to form a dense structure on top of the iron alloy surface (Fig. 6). The dark layer (2) consists of a compact and continuous magnetite crust, in intimate connection with the underlying lepidocrocite of layer (1) (Fig. 7). The bright orange layer (3) appears as fine, $2-3 \mathrm{~mm}$ wide, aggregates of acicular goethite, occurring in discrete localities on

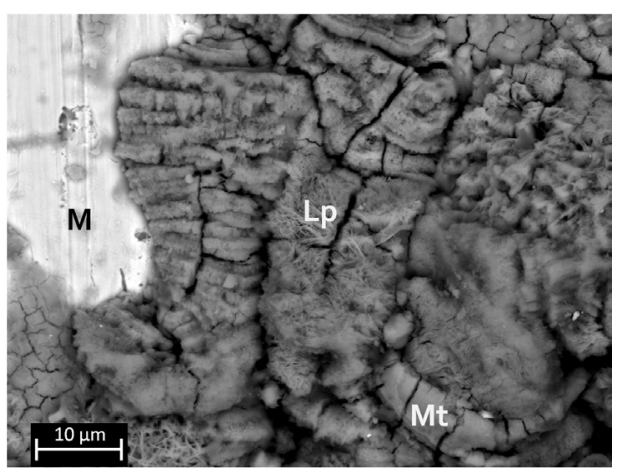

Fig. 6. SEM-BSE image of platey lepidocrocite (Lp) crystals stacked and interlocked to form a dense structure on top of the metal (M) surface. Magnetite (Mt) is also visible in this image.

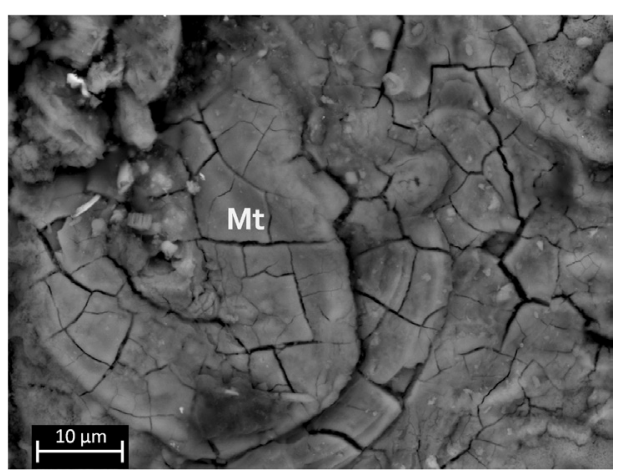

Fig. 7. SEM-BSE image of compact and continuous magnetite (Mt) crust.

top of and mixed with lesser amounts of lepidocrocite plates measuring up to $5 \mu \mathrm{m}$ in length (Fig. 8). 


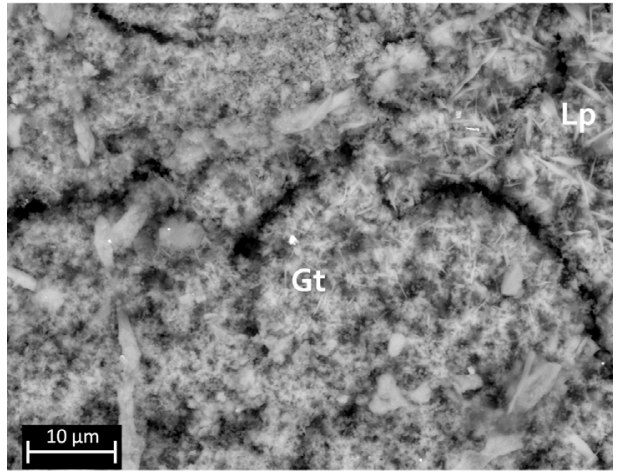

Fig. 8. SEM-BSE image of fine aggregates of acicular goethite (Gt) and mixed with lesser amounts of lepidocrocite (Lp) plates.

Examined by SEM, the translucent layer (4) presents as a continuous film, up to 20 $\mu \mathrm{m}$ thick, covering the other corrosion layers (Fig. 9). Under normal light, the color of

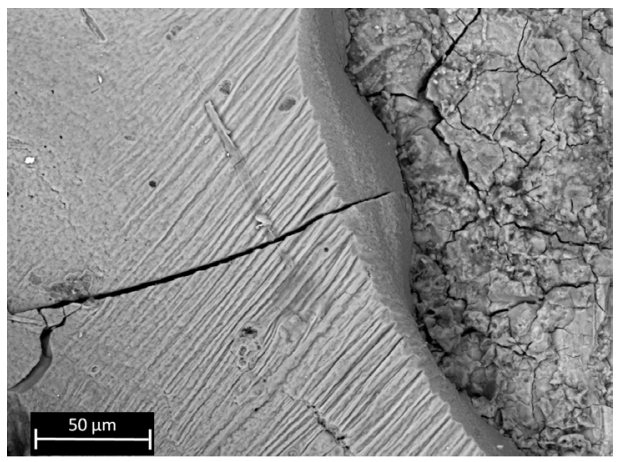

Fig. 9. SEM-BSE image of layer (4) continuous film over the corrosion crust.

this film varies from black to bright yellow, dependent on the color of the underlying iron oxide or oxyhydroxide. SEM-SE observation of the translucent material at low $\mathrm{kV}$ revealed a thin layer of sub-micron, rod-like particles measuring a few nanometers in diameter (Fig. 10). Further characterization of the material by FTIR identified iron oxalates, goethite corrosion, and an organic component of lipids and/or waxes (Fig. 11).

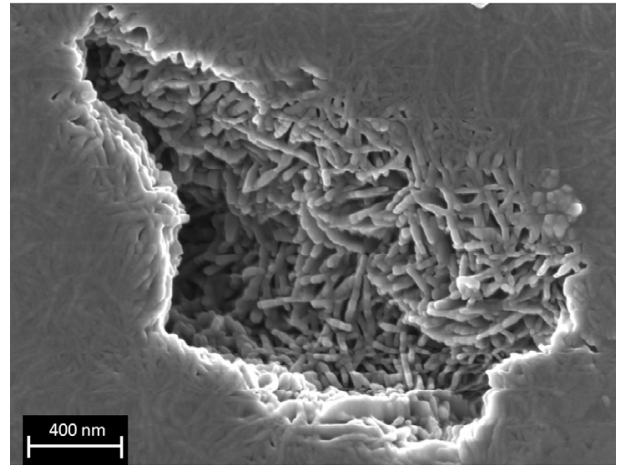

Fig. 10. SEM-SE image of layer (4) showing sub-micron, rod-like iron oxalates.

Iron oxalate formation may be associated with degradation of surface organic materials or possibly with metabolic corrosion processes of bacillus bacterial colonies found in areas on the scale's surface [39-46]. THMGC-MS confirmed the presence of wax and lipids, with fatty acids possibly from multiple sources (oils, fat, wax, soil).

To verify and complement the SEM-EDS/ BSE/SE characterization of the surface corrosion, scraping samples of each layer (1), (2), and (3) were collected for further investigation by Raman spectroscopy. It is noted that under certain Raman measurement conditions it is possible to induce some peak broadening in various phases of iron oxides and iron oxyhydroxides, and that magnetite in particular can experience a phase transformation to hematite [47-50]. However, good quality Raman spectra were not obtained in this study at lower power levels, therefore higher power measurement settings were employed. The Raman spectrum of layer (1) exhibits the primarily singular presence of lepidocrocite, indicated by peaks at $250 \mathrm{~cm}^{-1}$, $381 \mathrm{~cm}^{-1}$, and $533 \mathrm{~cm}^{-1}$; consistent with SEM findings, no other corrosion species were detected in layer (1) by Raman (Fig. 12). The Raman spectrum of layer (2) featured large 


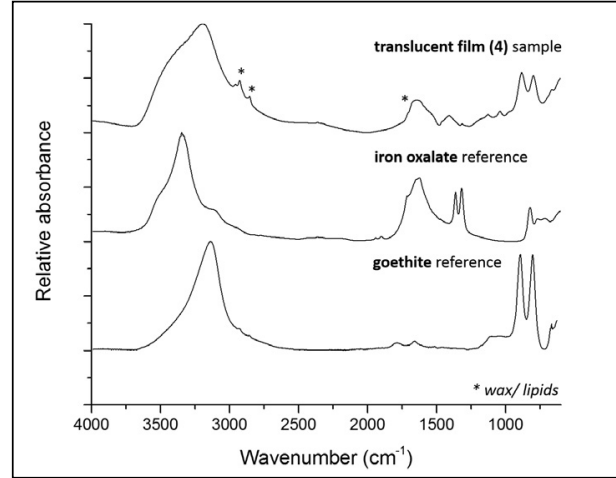

Fig. 11. FTIR spectra comparison of layer (4) with reference spectra of iron oxalate (main peaks around $3340,1648,1380,1317 \mathrm{~cm}^{-1}$ ) and goethite (diagnostic peaks at 800 and $889 \mathrm{~cm}^{1}$ ) and absorption bands of waxes and lipids $\left(^{*}\right)$.

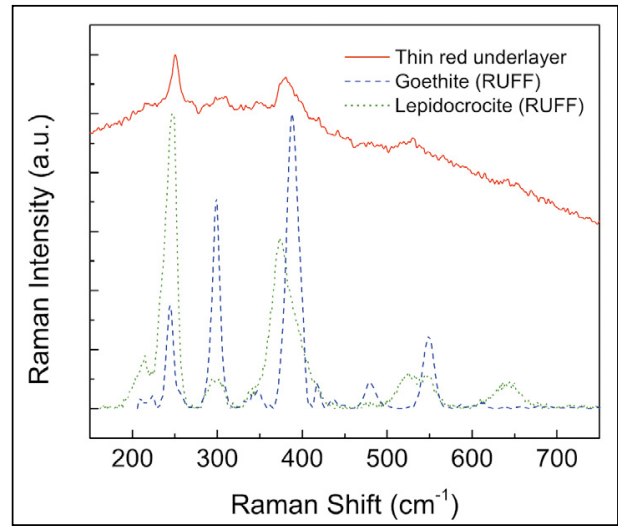

Fig. 12. Raman spectra comparison of layer (1) exhibiting the primarily singular presence of lepidocrocite with peaks at $250 \mathrm{~cm}^{-1}, 381 \mathrm{~cm}^{-1}$, and $533 \mathrm{~cm}^{-1}$.

amounts of fluorescence which inhibited the identification of corrosion species content (Fig. 13). This fluorescence is attributed to significant amounts of fluorescent organic matter contaminants, such as fibers, from the scale's surface; the lack of distinctive peaks could also result from the low Raman activity of magnetite, indicated by SEM as the layer's primary component [51]. The

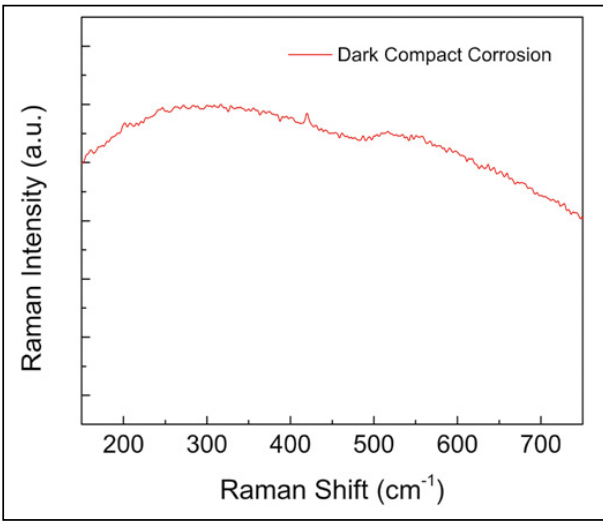

Fig. 13. Raman spectra comparison of layer (2) featuring large amounts of fluorescence, which inhibited the identification of corrosion species content.

Raman spectrum of layer (3) shows the presence of goethite, indicated by peaks at $300 \mathrm{~cm}^{-1}, 386 \mathrm{~cm}^{-1}$, and $549 \mathrm{~cm}^{-1}$ and consistent with SEM findings (Fig. 14). No other substances are evident in the Raman spectrum of layer (3), including the lepidocrocite observed in the SEM scans; this is likely due to the lesser amounts of lepidocrocite observed under SEM combined with

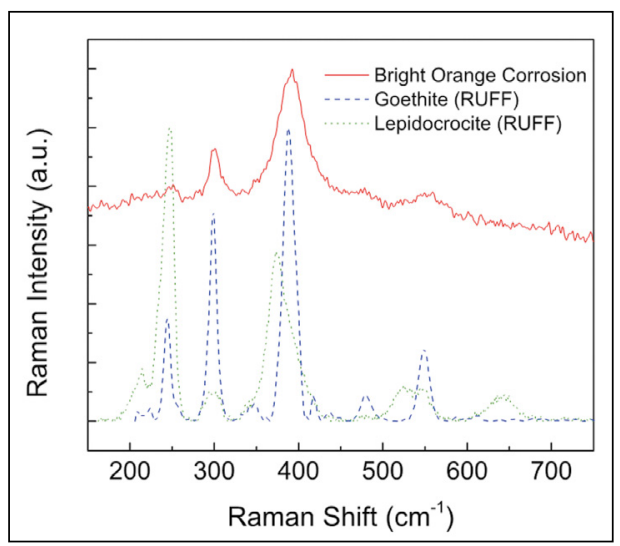

Fig. 14. Raman spectra comparison of layer (3) showing the presence of goethite with peaks at $300 \mathrm{~cm}^{-1}$, $386 \mathrm{~cm}^{-1}$, and $549 \mathrm{~cm}^{-1}$. 
the similar Raman activity levels of goethite and lepidocrocite [52].

Based on these analyses, a simplified stratigraphy of corrosion products on the surface of the metal scales can be summarized, with local variations and a maximum thickness of $500 \mu \mathrm{m}$, as follows: a lowest layer (1) of matte, red lepidocrocite platy crystals ranging in size from $1-5 \mu \mathrm{m}$ which stack and interlock in a dense structure covering most of the metal surface, over which a layer (2) of compact, dark magnetite approximately $1 \mu \mathrm{m}$ thick is often present, further topped locally by a layer (3) consisting of bright orange goethite in fine acicular aggregates $2-3 \mu \mathrm{m}$ wide, mixed with less amounts of lepidocrocite plates measuring $5 \mu \mathrm{m}$ long. In some areas, a translucent layer (4) is present on top as a continuous film, up to $20 \mu \mathrm{m}$ thick and containing sub-micron, rod-like iron oxalates possibly associated with bacillus bacterial colonies in an oily-waxy substance.

Additional information was gained from the SEM-EDS/BSE/SE analysis of the scale surface and from the SEM-EDS analysis of the isolated layer scraping samples. Besides the corrosion products formed on the scale's surface, several foreign particles were identified. Among the most recurrent particles were silicates and other inorganic materials consistent with soiling contamination, with quartz and feldspar grains recognized. Organic material consisting primarily of textile fibers were also found embedded within the surface layers and may originate from the armor's textile support or incidental contamination.

\section{Laser Cleaning Tests}

Following characterization of the corrosion layers, laser cleaning tests were performed to establish the damage threshold of the metal substrate and to evaluate the efficacy of various laser parameters in reducing the surface corrosion.

An Nd:YAG Q-switched laser was used at $1064 \mathrm{~nm}$ and $532 \mathrm{~nm}$ outputs with a pulse duration of $8 \mathrm{~ns}$ and a repetition rate of $2 \mathrm{~Hz}$. Fifty pulses were chosen as the experimental pulse number based on the variable thickness and composition of the surface corrosion layers which require a controlled and gradual reduction of corrosion layers. Mineral spirits was applied to the surface on a rolled cotton swab before laser cleaning to increase laser-induced corrosion removal and reduce the metal substrate's initial reactivity $[24,25$, $28,53]$. In areas of thicker corrosion, mineral spirits on a cotton swab was applied multiple times and also served as method of mild mechanical removal for material loosened during laser application.

The macroscopic damage threshold of the armor's iron alloy scale was empirically determined by applying laser pulses of the above parameters at each wavelength to a small, uncorroded region of the scale and gradually increasing the fluence until a very slight yellowing was visually observed after 50 pulses, indicating micromelting of the metal surface [2]. Effective fluences for corrosion removal were empirically found for each wavelength, constricted below the established macroscopic damage threshold and with diminishing results observed after 50 pulses. Cleaning tests were performed below the established damage thresholds and within the effective corrosion removal fluences, resulting in $175 \mathrm{~mJ} / \mathrm{cm}^{2}$ at 1064 $\mathrm{nm}$ and $90 \mathrm{~mJ} / \mathrm{cm}^{2}$ at $532 \mathrm{~nm}$. The tests were performed on two visually similar regions approximately $1 \mathrm{~cm}^{2}$ that possessed representative distributions of corrosion products. 
Comparative tests between laser cleaning with the $1064 \mathrm{~nm}$ infrared laser and the 532 $\mathrm{nm}$ green laser showed that a lower energy fluence could be employed using the $532 \mathrm{~nm}$ laser to produce more efficient iron corrosion reduction and significantly less risk of alteration to the underlying metal surface than could be achieved at the higher energy fluence required using the $1064 \mathrm{~nm}$ laser.

SEM - BSE images show magnifications of the metal scale surface after corrosion reduction utilizing laser cleaning at 1064 $\mathrm{nm}$ and at $532 \mathrm{~nm}$. Neither laser cleaning protocol completely removed all corrosion on the metal surface. It was not feasible in this study to take samples to compare the depth of surface layers before and after cleaning in order to obtain a more quantitative comparison of the amount of corrosion removal by each laser wavelength. However, the $100 \times$ magnification images show that a greater portion of corrosion was reduced by the $532 \mathrm{~nm}$ wavelength than by the 1064 $\mathrm{nm}$ wavelength, as evidenced in the greater revelation of the underlying metallic surface (Fig. 15-16). Images at higher magnification

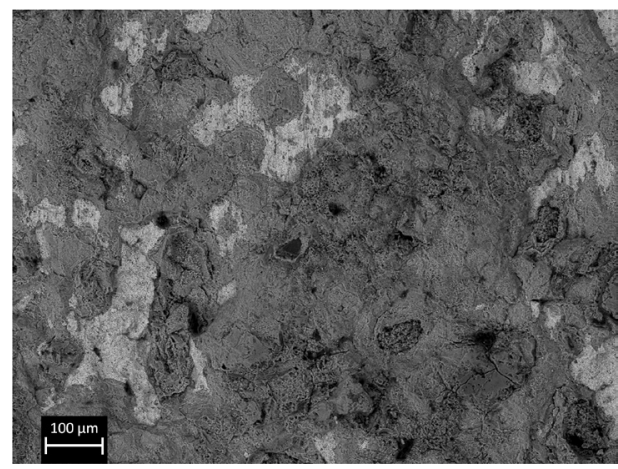

Fig. 15. SEM-BSE image $(100 \times)$ of surface of corroded metal armor scale after laser cleaning with $1064 \mathrm{~nm}$ at $0.175 \mathrm{~J} / \mathrm{cm}^{2}$ ( $8 \mathrm{~ns}, 2 \mathrm{~Hz}, 50$ pulses). Significant amount of corrosion remains on the surface, with some clean metal visible in local areas.

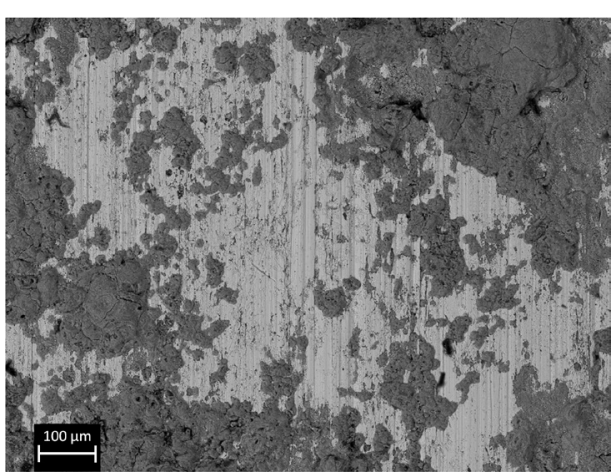

Fig. 16. SEM-BSE image $(100 \times)$ of surface of corroded metal armor scale after laser cleaning with $532 \mathrm{~cm}$ at $0.090 \mathrm{~J} / \mathrm{cm}^{2}$ (8 ns, $2 \mathrm{~Hz}, 50$ pulses). Some corrosion remains on the surface; however, significant areas of clean metal are also visible.

$(3100 \times)$ were taken to provide greater detail of the metallic surface as revealed by cleaning at each laser wavelength. The surface irradiated with $1064 \mathrm{~nm}$ laser pulses shows clear signs of significant micromelting, including bubbling, deformation, and metallic nanospheres (Fig. 17). The surface irradiated with $532 \mathrm{~nm}$ pulses, on the other hand, exhibits almost no signs of micromelting, except

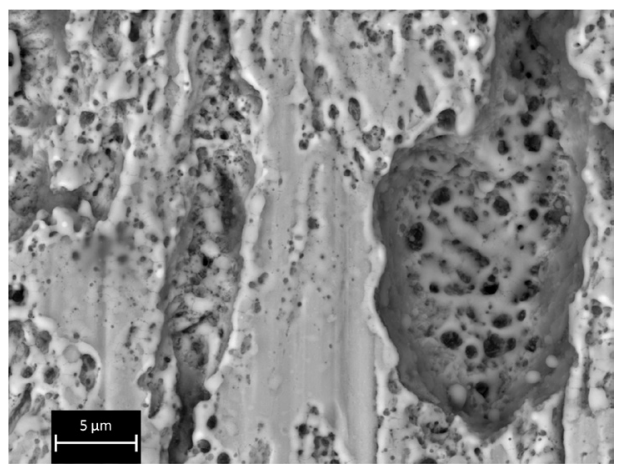

Fig. 17. SEM-BSE image (3100x) of surface of corroded metal armor scale after laser cleaning with $1064 \mathrm{~nm}$ at $0.175 \mathrm{~J} / \mathrm{cm}^{2}$ ( $8 \mathrm{~ns}, 2 \mathrm{~Hz}, 50$ pulses). The surface shows clear signs of significant micromelting, including bubbling, deformation, and metallic nanospheres. 
perhaps for a slight softening of some edges in pitted regions and several small, bright nanospheres (Fig. 18). These data suggest that the lower cleaning fluence at the $532 \mathrm{~nm}$ wavelength is both more effective in ferrous corrosion reduction and less damaging to the underlying iron alloy.

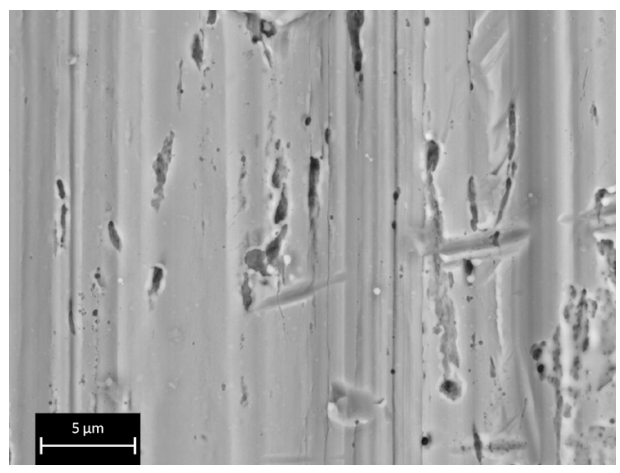

Fig. 18. SEM-BSE image $(3100 \times)$ of surface of corroded metal armor scale after laser cleaning with $532 \mathrm{~cm}$ at $0.090 \mathrm{~J} / \mathrm{cm}^{2}$ ( $8 \mathrm{~ns}, 2 \mathrm{~Hz}, 50$ pulses $)$. The surface exhibits almost no signs of micromelting, except perhaps for a slight softening of some edges in pitted regions and several small, bright nanospheres.

It is worth noting that after laser cleaning, a dark residue remained on portions of the surface. While conclusive characterization of this dark material was not pursued in this study, the observation is consistent with other investigations into the laser cleaning of iron surfaces in which the formation of hematite and/or magnetite induced by thermal effects and plasma generation from laser ablation processes results in a darkening of the cleaned metal surface $[4,19$, 24]. The thermal transformations amongst iron oxides and iron oxyhydroxides (in particular amongst goethite, magnetite, and hematite) are thoroughly researched by allied sciences [54-66] and for the cultural heritage community may indicate distinctions amongst laser cleaning parameters, such as pulse duration and thermal effects $[24,52]$.

\section{Discussion}

The improvement of the $532 \mathrm{~nm}$ treatment over the $1064 \mathrm{~nm}$ treatment can be attributed to more efficient and better localized energy transfer due to the optical scattering and absorption properties of each wavelength and of the iron oxide corrosion population as characterized.

Optical absorption by all detected iron oxide species increases dramatically at wavelengths less than $550 \mathrm{~nm}$ [67]. Absorption profiles extending from weak absorption in the near-IR to strong absorption in the near-UV is characteristic of ferric oxides and oxyhydroxides due to crystal field transitions [67]. This indicates that shorter wavelengths are closer to resonance for these electronic transitions and consequently should induce enhanced ablation from single- and multi-photon processes such as electronic-vibrational coupling and plasma generation, respectively [68]. This study further hypothesizes that, with increased optical scattering and absorption of the $532 \mathrm{~nm}$ wavelength by the iron oxides, more energy from the incident laser beam is absorbed by the upper corrosion layers and therefore less laser energy impinges on the underlying metal when cleaning at green wavelengths. Contrastingly, as less of the $1064 \mathrm{~nm}$ wavelength is absorbed by the corrosion layers, more energy is transmitted to the metal substrate, increasing the risk of damage and melting of the underlying metal during laser cleaning in the infrared.

In addition to strong absorption, shorter wavelengths experience increased scattering within iron corrosion layers and highly scat- 
tering media generate light intensity within the material greater than the incident intensity $[28,69]$. The scattering phenomenon in a laser-cleaned sample (in which the incident beam is much wider than the distance between scattering events) can be modeled analogous to the diffusion equation with light propagation approximated as a one-dimensional case with exact solutions $[70,71]$. The magnitude and distribution of light intensity in the sample have a complex relationship with several parameters including the spatial distribution of scattering events, the degree of scattering and absorption, and the thickness of the material [72]. The measurements needed to characterize these parameters were beyond the scope of this experiment; therefore, it was not possible to estimate the degree to which laser cleaning is dependent on wavelength-tunable scattering in the case of this study. However, in one-dimensional cases of light propagation in the diffusion equation, intensity increases due to scattering effects of 2-3x the incident light are not unusual [72]. This study posits that decreased scattering length at $532 \mathrm{~nm}$ as compared to $1064 \mathrm{~nm}$ limits the penetration depth of the laser energy and increases the effective fluence of each laser pulse nearer to the point of surface incidence, thereby allowing for a more localized impact of laser cleaning on the surface corrosion layers and a minimized load on the underlying metal substrate.

\section{Conclusions and further research}

In summary, the use of the $532 \mathrm{~nm}$ wavelength at a lower fluence produced more effective corrosion reduction and less alteration of the underlying iron surface than the use of the $1064 \mathrm{~nm}$ wavelength at a higher fluence. This result is attributed to increased retention of the incident laser energy within the corrosion layers and decreased penetration to the underlying metal surface due to increased optical absorption of shorter wavelengths by the iron oxide species and to increased and localized energy intensity within the corrosion layers due to decreased scattering length of shorter wavelengths.

Ultimately, in the practical treatment of the armor scales, laser cleaning was combined with traditional mechanical cleaning to produce optimal results. The incorporation of laser cleaning in the treatment protocol increased the overall time efficiency of the corrosion reduction by a factor of four (Figs. 19-20). Initial laser cleaning of the corroded

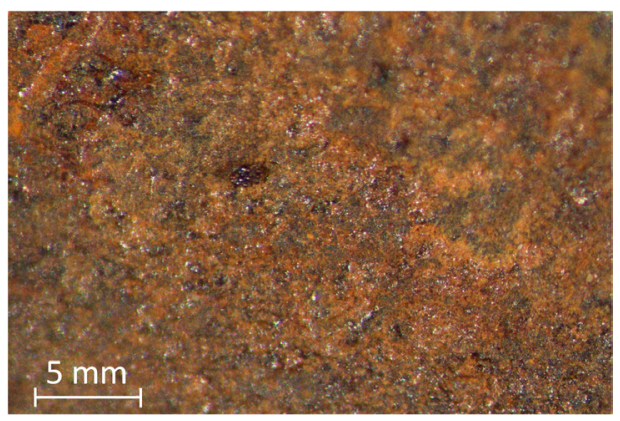

Fig. 19. Stereomicrograph of corroded surface of armor's metal scale before cleaning.

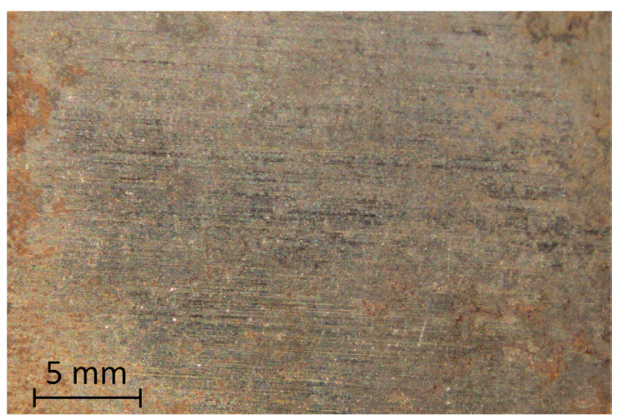

Fig. 20. Stereomicrograph of corroded surface of armor's metal scale after laser cleaning $(532 \mathrm{~nm}$ wavelength, $8 \mathrm{~ns}$ pulse duration, $2 \mathrm{~Hz}$ frequency, and $0.090 \mathrm{~J} / \mathrm{cm}^{2}$ fluence) and before mechanical cleaning. 
surface followed by mechanical cleaning performed with a scalpel blade allowed an increase in time-efficiency of treating the large metal surface area while protecting the adjacent sensitive textile and maintaining a finished surface appearance familiar to traditional techniques and established aesthetic expectations.

The research presented here is ongoing, as we strive to clarify and deepen our understanding of the effects of wavelength variances on the reduction of corrosion on iron surfaces. Relevant future studies would seek to model the heat-effected zone within the stratigraphy of the corrosion crust and the underlying metal and to identify any relevant wavelength-dependent components of thermal diffusion [12, 73-78]. Pulse duration and frequency could be introduced as variable factors within the study and ablation rates at different laser parameter combinations could be quantified $[79,80]$. Finally, investigative studies could be initiated into the potential for evaluating thermal transformations amongst iron oxides and oxyhydroxides under variable oxidizing/ reducing environments as an evaluative tool for the characterization and monitoring of the laser cleaning of iron alloys.

\section{Acknowledgements}

The authors thank The Metropolitan Museum of Art, the Smithsonian National Air and Space Museum, and Yale University for generous support of this research study. Special thanks are extended to The Met's Department of Scientific Research and Marco Leona, to The Met's Arms and Armor Department, Pierre Terjanian, and Edward Hunter, to The Met's Objects Conservation Department, Lawrence Becker, Lisa Pilosi, Carolyn Riccardelli, and Wendy Walker, and to the Smithsonian National Air and Space Museum's Conservation Unit and Malcolm Collum. We gratefully acknowledge Quanta System for providing the Thunder Art Laser to the Metropolitan Museum of Art. Further acknowledgements are offered to the Andrew W. Mellon Foundation, the National Endowment for the Humanities, and the Winterthur/University of Delaware Program in Art Conservation.

\section{References}

[1] M. Pires, C. Curran, W. Perrie, K. Watkins, "Laser cleaning: influence of laser beam characteristics", in: Lasers in the Conservation of Artworks (Proceedings of the International Conference LACONA VII), Madrid, Spain, 17-21 September 2007, M. Castillejo, P. Moreno, M. Oujja, R. Radvan, J. Ruiz (Eds.), CRC Press, Boca Raton 2008, pp. 329-333.

[2] A. Siatou, D. Charalambous, V. Argyropoulos, P. Pouli, "A comprehensive study for the laser cleaning of corrosion layers due to environmental pollution for metal objects of cultural value: preliminary studies on artificially corroded coupons", Laser Chemistry, (2006), Article ID 85324, DOI: 10.1155/2006/85324 (accessed: 17.06.2017).

[3] P. Mottner, G. Wiedemann, G. Haber, W. Conrad, A. Gervais, "Laser cleaning of metal surface - laboratory investigation", in: Lasers in the Conservation of Artworks (LACONA V Proceedings), Osnabrück, Germany, September 15-18, 2003, K. Dickmann, C. Fotakis, J. Asmus (Eds.), Springer, Berlin 2005, pp. 79-86.

[4] C. Cottam, D. Emmony, "TEA-CO2 laser surface processing of corroded metals", Corrosion Science 41 (1999) 1529-1538, DOI: 10.1016/S0010938X(98)00202-9.

[5] M. De Giorgi, E. D’Anna, A. Della Patria, H. De Rosa, A. Lorusso, P. Orfanou, A. Perrone, "Laser cleaning of copper-based coins", in: Lasers in the Conservation of Artworks IX (Proceedings of the International Conference on LACONA IX), London, United Kingdom, 07-10 September 2011, D. Saunders, M. Strlič, C. Korenberg, N. Luxford, K. Birkhölzer (Eds.), Archetype Publications, London 2013, pp. 192-193.

[6] H. Garbacz, E. Fortuna-Zaleśna, J. Marczak, M. Strzelec, A. Koss, A. Zatorska, "Evaluation of laser cleaning of old copper roofing and gilding using tun- 
able length laser pulses", in: Lasers in the Conservation of Artworks IX (Proceedings of the International Conference on LACONA IX), London, United Kingdom, 07-10 September 2011, D. Saunders, M. Strlič, C. Korenberg, N. Luxford, K. Birkhölzer (Eds.), Archetype Publications, London 2013, pp. 204-206.

[7] A. Dajnowski, A. Lins, "The practical use of lasers in removing deteriorated Incralac coatings from large bronze monuments", in: Lasers in the Conservation of Artworks VIII (Proceedings of the International Conference on LACONA VIII), Sibiu, Romania, 21-25 September 2009, R. Radvan, J. Asmus, M. Castillejo, P. Pouli, A. Nevin (Eds.), CRC Press, London 2011, pp. 47-52.

[8] A. Dajnowski, "Laser as a cleaning tool for the treatment of large-scale bronze monuments", in: Lasers in the Conservation of Artworks (Proceedings of the International Conference LACONA VII), Madrid, Spain, 17-21 September 2007, M. Castillejo, P. Moreno, M. Oujja, R. Radvan, J. Ruiz (Eds.), CRC Press, Boca Raton 2008, pp. 303-308.

[9] M. Froidevaux, P. Platt, M. Cooper, K. Watkins, "Laser interactions with copper, copper alloys and their corrosion products used in outdoor sculpture in the United Kingdom", in: Lasers in the Conservation of Artworks (Proceedings of the International Conference LACONA VII), Madrid, Spain, 17-21 September 2007, M. Castillejo, P. Moreno, M. Oujja, R. Radvan, J. Ruiz (Eds.), CRC Press, Boca Raton 2008, pp. 277-284.

[10] C. Korenberg, A. Baldwin, "Investigating the laser cleaning of archaeological copper alloys using different laser systems", in: Lasers in the Conservation of Artworks (Proceedings of the International Conference LACONA VII), Madrid, Spain, 17-21 September 2007, M. Castillejo, P. Moreno, M. Oujja, R. Radvan, J. Ruiz (Eds.), CRC Press, Boca Raton 2008, pp. 285-290.

[11] S. Agnoletti, A. Brini, L. Nicolai, "Current work in laser cleaning of the Porta del Paradiso", in: Lasers in the Conservation of Artworks (LACONA VI Proceedings), Vienna, Austria, 21-25 September 2005, J. Nimmrichter, W. Kautek, M. Schreiner (Eds.), Springer, Berlin 2007, pp. 29-36.

[12] S. Siano, R. Salimbeni, "The Gate of Paradise: physical optimization of the laser cleaning approach",
Studies in Conservation, 46 (2001) 269-281, DOI: 10.1179/sic.2001.46.4.269.

[13] R. Pini, S. Siano, R. Salimbeni, M. Pasquinucci, M. Miccio, "Tests of laser cleaning on archaeological metal artefacts", Journal of Cultural Heritage, 1 (2000) S129-S137, DOI: S1296-2074(00)00139-4/FLA .

[14] P. Fitzsimons, K. Watkins, A. El-Naggar, Z. Allen, "Removal of bronze gilding layers using a 20ps fibre laser", in: Lasers in the Conservation of Artworks IX (Proceedings of the International Conference on LACONA IX), London, United Kingdom, 07-10 September 2011, D. Saunders, M. Strlič, C. Korenberg, N. Luxford, K. Birkhölzer (Eds.), Archetype Publications, London 2013, pp. 201-203.

[15] M. Kono, K. Baldwin, A. Wain, M. Sawicki, I. Malkiel, A. Rode, "High repetition rate laser restoration and monitoring of large area gilded surfaces", in: Lasers in the Conservation of Artworks IX (Proceedings of the International Conference on LACONA IX), London, United Kingdom, 07-10 September 2011, D. Saunders, M. Strlič, C. Korenberg, N. Luxford, K. Birkhölzer (Eds.), Archetype Publications, London 2013, pp. 45-51.

[16] M. Barrera, C. Escudero, D. Ynsa, A. Climent-Font, "Application of ion beam analysis (IBA) techniques for the assessment of laser cleaning on gilded copper", in: Lasers in the Conservation of Artworks (Proceedings of the International Conference LACONA VII), Madrid, Spain, 17-21 September 2007, M. Castillejo, P. Moreno, M. Oujja, R. Radvan, J. Ruiz (Eds.), CRC Press, Boca Raton 2008, pp. 323-328.

[17] M. Panzer, G. Wiedemann, M. Meier, W. Conrad, A. Kempe, T. Hutsch, "Laser cleaning of gildings", in: Lasers in the Conservation of Artworks (LACONA VI Proceedings), Vienna, Austria, 21-25 September 2005, J. Nimmrichter, W. Kautek, M. Schreiner (Eds.), Springer, Berlin 2007, pp. 21-28.

[18] A. Dajnowski, B. Dajnowski, “A case study in the removal of paint and corrosion from cast iron using a Nd:YAG laser", in: Lasers in the Conservation of Artworks IX (Proceedings of the International Conference on LACONA IX), London, United Kingdom, 07-10 September 2011, D. Saunders, M. Strlič, C. Korenberg, N. Luxford, K. Birkhölzer (Eds.), Archetype Publications, London 2013, pp. 40-44. 
[19] J. Resende, A. Hipólito, M. Pires, "Modification of iron corrosion after pulsed laser irradiation", in: Lasers in the Conservation of Artworks IX (Proceedings of the International Conference on LACONA IX), London, United Kingdom, 07-10 September 2011, D. Saunders, M. Strlič, C. Korenberg, N. Luxford, K. Birkhölzer (Eds.), Archetype Publications, London 2013, pp. 176-178.

[20] I. Khalfallah, M. Rahoma, J. Abboud, K. Benyounis, "Microstructure and corrosion behavior of austenitic stainless steel treated with laser", Optics \& Laser Technology, 43 (2011) 806-813, DOI: 10.1016/j. optlastec.2010.11.006 .

[21] C. Korenberg, A. Baldwin, "Laser cleaning of iron: surface appearance and re-corrosion of model systems", in: Lasers in the Conservation of Artworks VIII (Proceedings of the International Conference on LACONA VIII), Sibiu, Romania, 21-25 September 2009, R. Radvan, J. Asmus, M. Castillejo, P. Pouli, A. Nevin (Eds.), CRC Press, London 2011, pp. 123-128.

[22] K. Alabeedi, J. Abboud, K. Benyounis, "Microstructure and erosion resistance enhancement of nodular cast iron by laser melting", Wear, 266 (2009) 925-933, DOI: 10.1016/j.wear.2008.12.015 .

[23] J. Chamón, J. Barrio, E. Catalán, M. Arroyo, A. Pardo, "Nd:YAG laser cleaning of heavily corroded archaeological iron objects and evaluation of its effects", in: Lasers in the Conservation of Artworks (Proceedings of the International Conference LACONA VII), Madrid, Spain, 17-21 September 2007, M. Castillejo, P. Moreno, M. Oujja, R. Radvan, J. Ruiz (Eds.), CRC Press, Boca Raton 2008, pp. 297-302.

[24] C. Korenberg, A. Baldwin, "Investigating and optimising the laser cleaning of corroded iron", in: Lasers in the Conservation of Artworks (Proceedings of the International Conference LACONA VII), Madrid, Spain, 17-21 September 2007, M. Castillejo, P. Moreno, M. Oujja, R. Radvan, J. Ruiz (Eds.), CRC Press, Boca Raton 2008, pp. 291-296.

[25] Y. Koh, J. Powell, A. Kaplan, J. Carlevi, "Laser cleaning of corroded steel surfaces: a comparison with mechanical cleaning methods", in: Lasers in the Conservation of Artworks (LACONA VI Proceedings), Vienna, Austria, 21-25 September 2005, J. Nim- mrichter, W. Kautek, M. Schreiner (Eds.), Springer, Berlin 2007, pp. 13-20.

[26] Y. Koh, J. Powell, A. Kaplan, "The removal of layers of corrosion from steel surfaces: a comparison of laser methods and mechanical techniques", Journal of Laser Applications 19 (2007) 99-106, DOI: 10.2351/1.2567378.

[27] Y. Koh, I. Sárady, "Cleaning of corroded iron artifacts using pulsed TEA $\mathrm{CO}_{2}$ and Nd:YAG-lasers", Journal of Cultural Heritage, 4, (2003) 129-133, DOI: 10.1016/S1296-2074(02)01140-8.

[28] K. Dickmann, J. Hildenhagen, J. Studer, E. Müsch, "Archaeological ironwork: removal of corrosion layers by Nd:YAG-laser", in: Lasers in the Conservation of Artworks (LACONA V Proceedings), Osnabrück, Germany, September 15-18, 2003, K. Dickmann, C. Fotakis, J. Asmus (Eds.), Springer, Berlin 2005, pp. 71-77.

[29] Y. Koh, I. Sárady, "Surface cleaning of iron artefacts by lasers", in: Lasers in the Conservation of Artworks (LACONA V Proceedings), Osnabrück, Germany, September 15-18, 2003, K. Dickmann, C. Fotakis, J. Asmus (Eds.), Springer, Berlin 2005, pp. 95-100.

[30] J. Asmus, "President Kennedy in Dallas: Dealey Plaza memorialized", Optical Metrology for Arts and Multimedia, 6618 (2007) 139-144, DOI: 10.1117/12.724292.

[31] J. Asmus, "Photonic restoration of marine artifacts and vessels of New Spain", in: Lasers in the Conservation of Artworks (Proceedings of the International Conference LACONA VII), Madrid, Spain, 17-21 September 2007, M. Castillejo, P. Moreno, M. Oujja, R. Radvan, J. Ruiz (Eds.), CRC Press, Boca Raton 2008, pp. 1-8.

[32] J. Brannon, J. Asmus, "Citric acid augmented flashlamp cleaning of corroded steel surfaces", Applications of Surface Science, 9 (1981) 14-21, DOI: 10.1016/0378-5963(81)90022-2 .

[33] C. Fotakis, D. Anglos, V. Zafiropulos, S. Georgiou, V. Tornari, Lasers in the Preservation of Cultural Heritage, Taylor and Francis, New York 2006.

[34] T. Burmester, M. Meier, H. Haferkamp, S. Barcikowski, J. Bunte, A. Ostendorf, "Femtosecond laser cleaning of metallic cultural heritage and antique 
artworks", in: Lasers in the Conservation of Artworks (LACONA V Proceedings), Osnabrück, Germany, September 15-18, 2003, K. Dickmann, C. Fotakis, J. Asmus (Eds.), Springer, Berlin 2005, pp. 61-69.

[35] S. Grancsay, "A Renaissance brigandine", The Metropolitan Museum of Art Bulletin, 37 (1942) 132-136, DOI: $10.2307 / 3256979$.

[36] The Metropolitan Museum of Art Collections Records 19.49.16, http://www.metmuseum.org/art/ collection $/$ search $/ 33499 ?=\&$ imgNo=0 $\&$ tabName $=$ re lated-objects (accessed 03.10.2016).

[37] B. Dean, Helmets and Body Armor in Modern Warfare, Yale University Press, New Haven 1920.

[38] B. Dean, Helmets and Body Armor in Modern Warfare, Yale University Press, New Haven 1920, pp. 59.

[39] H. Ashassi-Sorkhabi, M. Moradi-Haghighi, G. Zarrini, R. Javaherdashti, "Corrosion behavior of carbon steel in the presence of two novel iron-oxidizing bacteria isolated from sewage treatment plants", Biodegradation, 23 (2012) 69-79, DOI: 10.1007/ s10532-011-9487-8.

[40] L. Herrera, H. Videla, "Role of iron-reducing bacteria in corrosion and protection of carbon steel", International Biodeterioration \& Biodegradation, 63 (2009) 891-895, DOI: 10.1016/j.ibiod.2009.06.003.

[41] R. Jack, D. Ringelberg, D. White, "Differential corrosion rates of carbon steel by combinations of Bacillus sp., Hafnia alvei, and Desulfovibrio gigas established by phospholipid analysis of electrode biofilm", Corrosion Science, 33 (1992) 1843-1853, DOI: 10.1016/0010-938X(92)90188-9.

[42] B. Little, P. Wagner, "Microbiologically Influenced Corrosion", in: Peabody's Control of Pipeline Corrosion: $2^{\text {nd }}$ Edition, A. Peabody, R. Bianchetti (Eds.), NACE International, The Corrosion Society, Houston, Texas 2001, pp. 273-284.

[43] A. Rajasekar, B. Anandkumar, S. Maruthamuthu, Y. Ting, P. Rahman, "Characterization of corrosive bacterial consortia isolated from petroleum-product-transporting pipelines", Applied Microbiology and Biotechnology, 85 (2010) 1175-1188, DOI: $10.1007 / \mathrm{s} 00253-009-2289-9$.

[44] A. Rajasekar, Y. Ting, "Role of inorganic and organic medium in the corrosion behavior of Bacillus megaterium and Pseudomonas sp. in stainless steel SS 304", Industrial \& Engineering Chemistry Research, 50 (2011) 12534-12541, DOI: 10.1021/ie200602a.

[45] D. Xu, Y. Li, F. Song, T. Gu, "Laboratory investigation of microbiologically influenced corrosion of C1018 carbon steel by nitrate reducing bacterium Bacillus licheniformis", Corrosion Science, 77 (2013) 385-390, DOI: 10.1016/j.corsci.2013.07.044.

[46] K. Zarasvand, V. Rai, "Microorganisms: induction and inhibition of corrosion in metals", International Biodeterioration \& Biodegradation, 87 (2014) 66-74, DOI: 10.1016/j.ibiod.2013.10.023.

[47] D. de Faria, S. Venancio Silva, M. de Oliveira, "Raman microspectroscopy of some iron oxides and oxyhydroxides", Journal of Raman Spectroscopy, 28 (1997) 873-878, DOI: 10.1002/(SICI)10974555(199711)28:11<873::AID-JRS177>3.0.CO;2-B.

[48] O. Shebanova, P. Lazor, "Raman study of magnetite $\left(\mathrm{Fe}_{3} \mathrm{O}_{4}\right)$ : laser-induced thermal effects and oxidation", Journal of Raman Spectroscopy, 34 (2003) 845-852, DOI: $10.1002 /$ jrs. 1056 .

[49] O. Shebanova, P. Lazor, "Raman spectroscopic study of magnetite $\left(\mathrm{FeFe}_{2} \mathrm{O}_{4}\right)$ : a new assignment for the vibrational spectrum", Journal of Solid State Chemistry, 174 (2003) 424-430, DOI: 10.1016/ S0022-4596(03)00294-9.

[50] T. Glotch, M. Kraft, “Thermal transformations of akaganéite and lepidocrocite to hematite: assessment of possible precursors to Martian crystalline hematite", Physics and Chemistry of Minerals, 35 (2008) 569-581, DOI: 10.1007/s00269-008-0249-z .

[51] M. Hanesch, "Raman spectroscopy of iron oxides and (oxy)hydroxides at low laser power and possible applications in environmental magnetic studies", Geophysical Journal International, 177 (2009) 941-948, DOI: 10.1111/j.1365-246X.2009.04122.x.

[52] S. Oh, D. Cook, H. Townsend, "Characterization of iron oxides commonly formed as corrosion products on steel", Hyperfine Interactions, 112 (1998) 59-66.

[53] A. Sarzyński, K. Jach, J. Marczak, "Comparison of wet and dry laser cleaning of artworks", in: Lasers in the Conservation of Artworks (LACONA VI Proceedings), Vienna, Austria, 21-25 September 
2005, J. Nimmrichter, W. Kautek, M. Schreiner (Eds.), Springer, Berlin 2007, pp. 161-167.

[54] V. An, E. Ivchenko, C. de Izarra, "Laser induced oxidation processes in iron, copper and nickel nanopowders", Material Letter, 62 (2008) 2211-2214, DOI: 10.1016/j.matlet.2007.11.049.

[55] Y. Cudennec, A. Lecerf, "Topotactic transformations of goethite and lepidocrocite into hematite and maghemite", Solid State Sciences, 7 (2005) 520-529, DOI: 10.1016/j.solidstatesciences.2005.02.002.

[56] L. Davidson, S. Shaw, L. Benning, "The kinetics and mechanisms of schwertmannite transformation to goethite and hematite under alkaline conditions", American Mineralogist, 93 (2008) 1326-1337, DOI: 10.2138/am.2008.2761.

[57] D. de Faria, F. Lopes, "Heated goethite and natural hematite: can Raman spectroscopy be used to differentiate them?", Vibrational Spectroscopy, 45 (2007) 117-121, DOI: 10.1016/j.vibspec.2007.07.003.

[58] L. Diamandescu, D. Mihàilà-Tàràbàşanu, M. Feder, "On the solid phase transformation goethite - hematite”, Material Letters, 17 (1993) 309-311, DOI: 10.1016/0167-577X(93)90019-T.

[59] H. Fan, B. Song, Q. Li, "Thermal behavior of goethite during transformation to hematite", Materials Chemistry and Physics, 98 (2006) 148-153, DOI: 10.1016/j.matchemphys.2005.09.005.

[60] S. Gialanella, F. Girardi, G. Ischia, I. Lonardelli, M. Mattarelli, M. Montagna "On the goethite to hematite phase transformation", Journal of Thermal Analysis and Calorimetry, 102 (2010) 867-873, DOI: 10.1007/s10973-010-0756-2.

[61] G. González, A. Sagarzazu, R. Villalba, "Study of the mechano-chemical transformation of goethite to hematite by TEM and XRD", Materials Research Bulletin, 35 (2000) 2295-2308, DOI: 10.1016/S00255408(00)00434-7.

[62] F. Jia, K. Ramirez-Muñiz, S. Song, “Mechanism of the formation of micropores in the thermal decomposition of goethite to hematite", Surface and Interface Analysis, 47 (2015) 535-539, DOI: 10.1002/ sia. 5744 .

[63] L. Löffler, W. Mader, "Anisotropic x-ray peak broadening and twin formation in hematite derived from natural and synthetic goethite", Journal of the
European Ceramic Society, 26 (2006) 131-139, DOI: 10.1016/j.jeurceramsoc.2004.09.032.

[64] L. Pérez-Maqueda, J. Criado, C. Real, J. Šubrt, J. Boháček, "The use of constant rate thermal analysis (CRTA) for controlling the texture of hematite obtained from the thermal decomposition of goethite", Journal of Materials Chemistry, 9 (1999) 1839-1845, DOI: 10.1039/a901098j.

[65] K. Przepiera, A. Przepiera, "Kinetics of thermal transformations of precipitated magnetite and goethite", Journal of Thermal Analysis and Calorimetry, 65 (2001) 497-503, DOI: 10.1023/A:1012441421955.

[66] D. Walter, G. Buxbaum, W. Laqua, "The mechanism of the thermal transformation from goethite to hematite", Journal of Thermal Analysis and Calorimetry, 63 (2001) 733-748, DOI: 10.1023/A:1010187921227.

[67] R. Morris, H. Lauer, C. Lawson, E. Gibson, G. Nace, C. Stewart, "Spectral and other physicochemical properties of submicron powders of hematite $\left(\alpha-\mathrm{Fe}_{2} \mathrm{O}_{3}\right)$, maghemite $\left(\gamma-\mathrm{Fe}_{2} \mathrm{O}_{3}\right)$, magnetite $\left(\mathrm{Fe}_{3} \mathrm{O}_{4}\right)$, goethite $(\alpha-\mathrm{FeOOH})$, and lepidocrocite $(\gamma$-FeOOH)", Journal of Geophysical Research, 90 (1985) 3126-3144, DOI: 10.1029/JB090iB04p03126.

[68] R. Haglund, "Microscopic and mesoscopic aspects of laser-induced desorption and ablation", Applied Surface Science, 96-98 (1996) 1-13, DOI: 10.1016/0169-4332(95)00371-1.

[69] R. Cornell, U. Schwertmann, The Iron Oxides: Structure, Properties, Reactions, Occurrences and Uses: $2^{\text {nd }}$ Edition, WILEY-VCH Verlag GmbH \& Co. KGaA, Weinheim 2003, pp. 147-152.

[70] A. Ishimaru, "Diffusion of a pulse in densely distributed scatterers", Journal of the Optical Society of America, 68 (1978) 1045-1050, DOI: 10.1364/ JOSA.68.001045.

[71] S. Prahl, "Light transport in tissue", in: Doctoral thesis, University of Texas at Austin, United States 1988, http://omlc.org/ prahl/pubs/pdf/prahl88.pdf (accessed 09.10.2016).

[72] M. Van Gemert, S. Jacques, H. Sterenborg, W. Star, "Skin Optics", IEEE Transactions on Biomedical Engineering, 36 (1989) 1146-1154, DOI: 10.1109/10.42108. 
[73] A. Hassan, M. El-Nicklawy, M. El-Adawi, E. Nasr, A. Hemida, O. Abd El-Ghaffar, "Heating effects induced by a pulsed laser in a semi-infinite target in view of the theory of linear systems", Optics \& Laser Technology, 28 (1996) 337-343, DOI: 10.1016/0030-3992(95)00083-6.

[74] S. Kogou, A. Selimis, P. Pouli, S. Georgiou, C. Fotakis, "The role of the substrate in the laser cleaning process: a study on the laser assisted removal of polymeric consolidation materials from various substrates", in: Lasers in the Conservation of Artworks VIII (Proceedings of the International Conference on LACONA VIII), Sibiu, Romania, 21-25 September 2009, R. Radvan, J. Asmus, M. Castillejo, P. Pouli, A. Nevin (Eds.), CRC Press, London 2011, pp. 23-28.

[75] E. Saavedra, A. López, M. Fiorucci, J. Lamas, A. Ramil, T. Rivas, "Laser cleaning of granitic stones: modeling the heat-affected zone by means of a finite elements method", in: Lasers in the Conservation of Artworks IX (Proceedings of the International Conference on LACONA IX), London, United Kingdom, 07-10 September 2011, D. Saunders, M. Strlič, C. Korenberg, N. Luxford, K. Birkhölzer (Eds.), Archetype Publications, London 2013, pp. 243-245.

[76] E. Saavedra, A. Ramil, A. López, J. Álvarez, "Laser hardening of XC42 steel: numerical analysis of quenched area", Materials Science Forum, 636-637
(2010) 1165-1171, DOI: 10.4028/www.scientific.net/ MSF.636-637.1165.

[77] B. Taarnskov, P. Pouli, J. Bredal-Jørgensen, "Laser cleaning studies for the removal of tarnishing from silver and gilt silver threads in silk textiles", in: Lasers in the Conservation of Artworks VIII (Proceedings of the International Conference on LACONA VIII), Sibiu, Romania, 21-25 September 2009, R. Radvan, J. Asmus, M. Castillejo, P. Pouli, A. Nevin (Eds.), CRC Press, London 2011, pp. 67-73.

[78] N. Vasantgadkar, U. Bhandarkar, S. Joshi, "A finite element model to predict the ablation depth in pulsed laser ablation", Thin Solid Films, 519 (2010) 1421-1430, DOI: 10.1016/j.tsf.2010.09.016.

[79] S. Siano, M. Giamello, L. Bartoli, A. Mencaglia, V. Parfenov, R. Salimbeni, "Phenomenological characterisation of stone cleaning by different laser pulse duration and wavelength", in: Lasers in the Conservation of Artworks (LACONA VI Proceedings), Vienna, Austria, 21-25 September 2005, J. Nimmrichter, W. Kautek, M. Schreiner (Eds.), Springer, Berlin 2007, pp. 87-96.

[80] W. Svendsen, J. Schou, B. Thestrup, O. Ellegaard, "Ablation from metals induced by visible and UV laser irradiation”, Applied Surface Science, 96-98 (1996) 518-521, DOI: 10.1016/0169-4332(95)00506-4. 
